\title{
SUMO-Activating Enzyme Subunit 2
}

National Cancer Institute

\section{Source}

National Cancer Institute. SUMO-Activating Enzyme Subunit 2. NCI Thesaurus. Code C101570.

SUMO-activating enzyme subunit 2 ( $640 \mathrm{aa}, \sim 71 \mathrm{kDa}$ ) is encoded by the human UBA2 gene. This protein plays a role in post-translational protein modification. 